\title{
PKM KELOMPOK PKK (ISTRI NELAYAN) KELURAHAN MOLAS KECAMATAN BUNAKEN KOTA MANADO PROVINSI SULAWESI UTARA TENTANG DIVERSIFIKASI PRODUK OLAHAN IKAN
}

\author{
Verly Dotulong dan Lita A. D. Y. Montolalu \\ Program Studi Teknologi Hasil Perikanan FPIK UNSRAT Manado. 95115. \\ E-mail: verlydotulong@yahoo.co.id
}

\begin{abstract}
ABSTRAK
Mitra sasaran program ini berlokasi di Lingkungan IV dan V Kelurahan Molas Kecamatan Bunaken Kota Manado. Penduduk Lingkungan IV hampir setengah berprofesi sebagai nelayan dan penduduk Lingkungan V lebih dari setengahnya berprofesi juga sebagai nelayan. Masyarakat nelayan ini sudah melakukan kegiatan sebagai nelayan secara turun temurun, dimana kegiatan melaut dilakukan oleh kaum pria, dan para wanita menjual ikan di pasar Tuminting (pasar terdekat dengan pemukiman), ada juga kaum wanita yang menjadi pedagang ikan segar keliling. Para wanita ini tergabung dalam kelo mpok organisasi kemasyarakatan PKK, dimana masing-masing kelompok akan diikutsertakan 3 orang kader dalam program kemitraan masyarakat (PKM) ini. Masalah yang dihadapi oleh nelayan di daerah ini apabila hasil tangkapan melimpah, harga ikan akan murah dan banyak yang tersisa tidak laku dijual, diolah seadanya misalnya dibakar atau digoreng. Tujuan kegiatan ini yaitu: (1) Memanfaatkan hasil tangkapan ikan yang melimpah, (2) Meningkatkan keterampilan kaum ibu (istri nelayan) dalam melakukan berbagai bentuk olahan ikan seperti nugget ikan dan kaki naga ikan sebagai pangan yang kaya gizi. Metode pelaksanaan yang akan diterapkan pada program ini yaitu: (1) Penyuluhan dan pelatihan diversifikasi olahan ikan, (2) Pendampingan dan (3) Evaluasi. Hasil yang dicapai dari kegiatan PKM ini yaitu terjadi peningkatan pengetahuan pada ibu-ibu PKK (istri nelayan) di Desa Molas tentang manfaat makan ikan bagi kesehatan dan bagaimana membuat nugget dan kaki naga ikan sebagai makanan sehat, bergizi dan mempunyai rasa yang lezat yang bisa dikembangkan sebagai skala usaha rumah tangga.
\end{abstract}

Kata kunci: PKK (istri nelayan), diversifikasi, nugget ikan, kaki naga ikan.

\section{PENDAHULUAN}

Produk perikanan seperti ikan mengandung protein yang tinggi, murah harganya, mudah diperoleh dan halal untuk semua golongan ditinjau dari segi kesehatan maupun dari segi agama. Produk-produk perikanan ini kini mulai dilirik oleh berbagai kalangan, karena mengandung nilai gizi yang tinggi serta tergolong dalam pangan fungsional yang baik untuk kesehatan (Saparinto, 2011). Belakangan ini berbagai olahan berbahan ikan mulai dikembangkan dengan prinsip surimi based product atau dikenal dengan produk bernilai tambah (value added product). Jenis produk tersebut meliputi bakso ikan, nugget ikan, kue ikan, kaki naga ikan dan sebagainya (Purnomo, 2002; Kumolontang dan Indriati, 2011; Masita dan Sukesi, 2015).

Gerakan Memasyarakatkan Makan Ikan (GEMARIKAN) adalah salah satu upaya Kementerian Kelautan dan Perikanan untuk meningkatkan konsumsi makan ikan bagi masyara- kat Indonesia (Anonimous, 2007). Berdasarkan Surat Keputusan Menteri Kelautan dan Perikanan RI Nomor 29/MEN/2006 tanggal 26 September 2006 dibentuk FORIKAN (Forum Peningkatan Konsumsi Ikan). FORIKAN bertujuan untuk mensosialisasikan dan mensinergikan program/kegiatan Program Nasional GEMARIKAN. Disamping itu forum ini juga memiliki upaya dalam mendorong pertumbuhan perekonomian nasional, peningkatan kualitas SDM Indonesia dan mendukung Program Ketahanan Pangan Nasional. Posisi FORIKAN ini sangat penting dalam upaya menunjang program pemerintah untuk peningkatan mutu dan diversifikasi produk olahan hasil perikanan, tetapi ironisnya kebanyakan masyarakat nelayan hingga saat ini masih hidup di bawah garis kemiskinan. Hal ini disebabkan karena tingkat pendidikan yang rendah dan pekerjaan sebagai nelayan diwariskan secara turun temurun tanpa pengetahuan yang baik tentang bagaimana mengolah ikan di saat hasil tangkapan melimpah. Berdasarkan hal di 
atas maka Fakultas Perikanan dan Ilmu Kelautan UNSRAT, Program Studi Teknologi Hasil Perikanan akan melakukan Program Kemitraan Masyarakat pada Kelompok PKK (istri nelayan) Kelurahan Molas.

Kelurahan ini termasuk di wilayah Kota Manado berjarak $12 \mathrm{~km}$ dari kampus UNSRAT, dan $4 \mathrm{~km}$ dari pusat Kota Manado. Penduduk Kelurahan Molas berjumlah 5.229 jiwa yang tersebar dari Lingkungan I sampai V dengan tingkat pendidikan SD 1.679 jiwa, SMP 853 jiwa, SLTA 836, Diploma 28 jiwa dan Sarjana/ S1 11 jiwa, sisanya adalah anak-anak balita, fasilitas pendidikan yang ada yaitu 3 SD dan 1 SMP. Penduduk yang berprofesi sebagai nelayan umumnya terdapat di Lingkungan IV dan $\mathrm{V}$, sehingga yang menjadi mitra sasaran program ini adalah ibu-ibu PKK yang terdapat di Lingkungan IV dan V yang adalah istri nelayan.

Tujuan dari kegiatan ini untuk melatih ibu-ibu PKK yang menjadi mitra mengenai teknologi diversifikasi (penganekargaman) olahan ikan seperti nugget ikan dan kaki naga ikan untuk peningkatan gizi dan menambah pendapatan serta memperluas wawasan ibu-ibu PKK dalam memandang olahan ikan sebagai prospek pengembangan usaha yang menjanjikan, sehingga menciptakan lapangan kerja baru. Kegiatan ini akan diikuti oleh 3 orang kader. Diversifikasi pangan adalah sebuah program yang mendorong masyarakat untuk memvariasikan makanan pokok yang dikonsumsinya sehingga tidak terfokus pada satu jenis makanan. Diversifikasi pangan berperan dalam pemenuhan kebutuhan gizi masyarakat sehingga nutrisi yang diterima tubuh dapat bervariasi dan seimbang (Permentan NO. 15, 2013).

\section{METODE PELAKSANAAN}

Metode pendekatan yang ditawarkan untuk mendukung realisasi Program Kemitraan Masyarakat ini adalah:

1. Penyuluhan

Penyuluhan diberikan kepada ibu-ibu PKK (istri nelayan) yang ada di Kelurahan Molas, Lingkungan IV dan V kota Manado yang bertujuan mengubah perilaku anggota kelompok ke arah yang lebih baik menyangkut perlunya diverfsifikasi olahan ikan yang dapat dikembangkan menjadi usaha bisnis di bidang pangan hasil perikanan.

2. Pelatihan

Setelah dilakukan penyuluhan terhadap anggota kelompok PKK, selanjutnya dilakukan pelatihan bagi ibu-ibu sebagai sasaran. Tujuan metode ini ialah untuk memberikan keterampilan dalam menghasilkan produk olahan ikan seperti nugget ikan, bakso ikan dan kaki naga ikan sebagai bentuk pemberdayaan kelompok mitra. Pemberdayaan dilakukan sebagai pemecahan masalah prioritas sebagai berikut:

a. Penerapan teknologi pengolahan hasil perikanan

b. Diversifikasi olahan hasil laut (nugget dan kaki naga ikan).

3. Pendampingan

Pendampingan dilakukan kepada kedua mitra meliputi penyuluhan dan pelatihan pembuatan nugget ikan dan kaki naga ikan dengan jangka waktu setiap minggu.

4. Evaluasi

Evaluasi dilaksanakan selama 1 bulan dengan membagikan lembaran cek list untuk menilai tingkat kesukaan terhadap produk dan membandingkan rasa ikan yang diolah dengan cara sebelum kegiatan PKM yaitu ikan kering dan ikan bakar dengan produk olahan hasil perikanan sesudah kegiatan PKM yaitu nugget, bakso dan kaki naga ikan (consumer preference).

\section{HASIL YANG DICAPAI}

\section{Pelaksanaan Kegiatan}

Berdasarkan hasil diskusi dengan kelompok mitra, ternyata mitra belum memiliki keterampilan dan pengetahuan mengenai cara pengolahan dan pemanfaatan hasil perikanan sisa yang melimpah, khususnya diversifikasi produk olahan ikan seperti nugget ikan dan kaki naga ikan. Berdasarkan kendala tersebut melalui program kemitraan masyarakat solusi yang ditawarkan diharapkan dapat menyelesaikan masalah yang dihadapi oleh Kelompok PKK dengan menerapkan teknologi tepat guna, ikan hasil tangkapan bisa dimanfaatkan, disamping untuk peningkatan gizi keluarga juga dapat dijadikan peluang bisnis dalam produk pangan olahan ikan yang akan berdampak pada peningkatan kesejahteraan keluarga.

Berdasarkan data hasil diskusi dengan kelompok mitra ditemukan beberapa masalah prioritas yang perlu ditangani, yaitu:

1. Keterbatasan pengetahuan kelompok PKK (istri nelayan) tentang penanganan ikan secara cepat, hati-hati dan saniter untuk menjaga mutu ikan masih baik sebelum diolah. 
2. Keterbatasan pengetahuan dan wawasan para kelompok PKK (istri nelayan) tentang diversifikasi olahan ikan serta nilai gizinya.

3. Keterbatasan pemahaman dalam teknologi pengolahan hasil perikanan.

Berdasarkan hal-hal di atas maka kegiatan yang dilakukan berupa penyuluhan, demonstrasi dan praktek pelatihan pengolahan (pendampingan) dan evaluasi tentang diversifikasi olahan ikan. Diharapkan setelah mengikuti kegiatan ini para peserta memiliki beberapa kemampuan diantaranya mampu mengolah rumput laut menjadi tepung, mengolah ikan hasil tangkapan melalui diversifikasi produk yang bernilai tambah seperti nugget ikan, bakso ikan dan kaki naga ikan yang disubstitusi dengan tepung rumput laut untuk menciptakan wirausaha produk olahan ikan substitusi rumput laut yang bergizi dan aman untuk dikonsumsi.

\section{Penyuluhan}

Kegiatan penyuluhan diawali dengan penjelasan tentang manfaat makan ikan terutama untuk ibu-ibu hamil dan anak-anak balita. Dalam penyuluhan ini dijelaskan tentang kandungan gizi ikan, dimana ikan mengandung protein yang sangat dibutuhkan untuk perkembangan otak anak dan asam lemak omega tiga yang sangat bermanfaat baik untuk kecerdasan anak-anak maupun untuk mencegah beberapa penyakit berbahaya bagi orang dewasa seperti tekanan darah tinggi dan jantung arteroklerosis. Penjelasan dilanjutkan dengan memberikan pengetahuan kepada mitra bahwa kesegaran ikan merupakan hal prioritas yang harus diperhatikan karena berhubungan dengan gizi dari ikan tersebut, sehingga penanganan ikan segar harus diperhatikan yaitu ikan harus ditangani dengan suhu rendah agar komponen gizinya tidak rusak dan dapat dimanfaatkan maksimal oleh konsumen. Dijelaskan pula bahwa agar supaya bisa meningkatkan selera makan ikan maka sangat penting melakukan diversifikasi olahan ikan selain untuk memperpanjang masa simpan, makanan olahan ikan juga membuat ikan digemari terutama oleh anak-anak balita. Beberapa produk olahan ikan yang mempunyai rasa yang gurih dan bentuk yang menarik adalah nugget ikan dan kaki naga ikan (Gambar 1).

Selain ibu-ibu PKK, Mitra yang hadir dalam kegiatan penyuluhan ini juga adalah ketua Kelurahan Molas dan para perangkat desa (Gambar 2). Dokumentasi pelaksanaan penyuluhan dalam kegiatan PKM tentang diversifikasi pengolahan ikan khususnya pengolahan nugget ikan dan kaki naga ikan di Desa Molas disajikan pada Gambar 3.

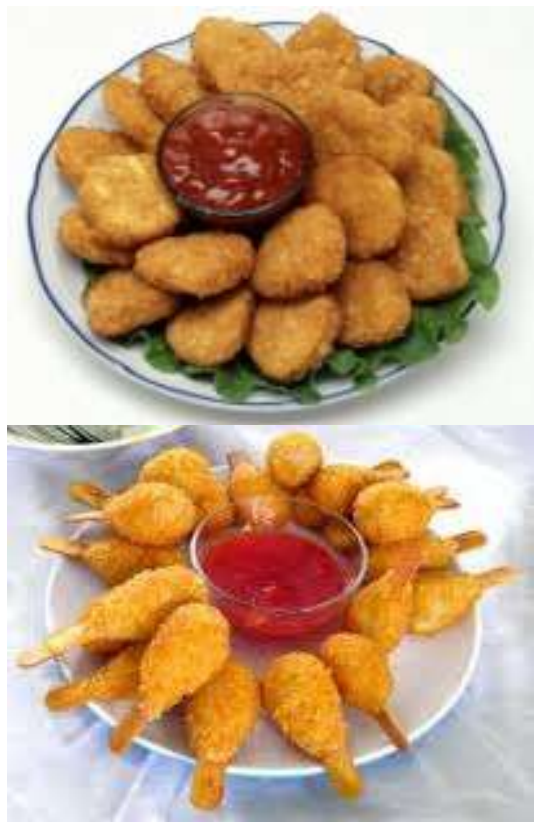

Gambar 1. Nugget ikan dan kaki naga ikan.

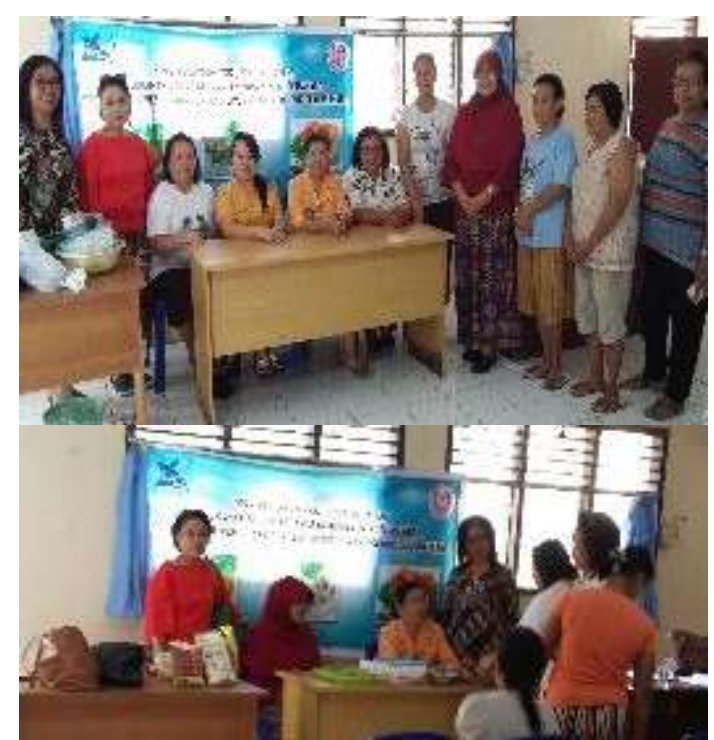

Gambar 2. Foto bersama dengan ibu Lurah Molas dan Perangkat Desa Molas.

Pelatihan diawali dengan memberikan penjelasan kembali tentang apa itu nugget ikan dan kaki naga ikan. Nugget ikan merupakan produk diversifikasi pengolahan hasil perikanan yang diadopsi dari luar Indonesia, berupa campuran daging ikan lumat dengan tepung tapioka, bumbu-bumbu berbentuk lempeng atau empat persegi panjang yang dilapisi tepung roti atau panir. Perbandingan yang baik yang akan menghasilkan nugget dengan tekstur dan rasa yang enak. Kaki Naga ikan adalah jenis olahan ikan dimana ikan ditambah tepung (tapioka, tepung bumbu) dibuat pasta dan ditambah 
bumbu-bumbu seperti: lada, garam, bawang Bombay, akar kuning dan telur, kemudian dibentuk bulat lonjong dan ditusuk dengan stik es krim, dikukus kemudian dilumuri tepung roti dan kemudian digoreng.

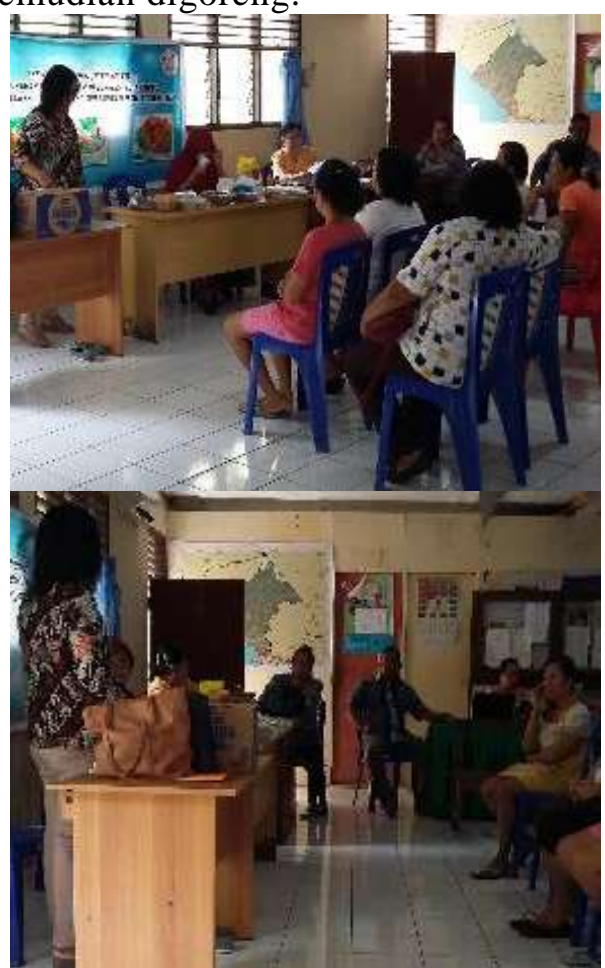

Gambar 3. Kegiatan penyuluhan tentang diversifikasi olahan ikan di Desa Molas

Pelatihan diberikan kepada mitra PKM tentang penyiapan bahan yang memenuhi syarat sanitasi untuk pembuatan kaki naga ikan dan nugget ikan selain lumatan daging ikan seperti beberapa jenis tepung (Gambar 4).

Tim PKM meragakan cara pembuatan nugget dan kaki naga ikan kepada mitra PKM (Gambar 5). Mitra PKM membuat nugget ikan dan kaki naga ikan sesuai dengan apa yang diajarkan oleh tim PKM menggunakan bahanbahan yang sudah disediakan didampingi oleh tim PKM (Gambar 7). Pendampingan dan evaluasi(Gambar 8) dilakukan hingga mitra benar-benar mengerti dan dapat membuat sendiri nugget dan produk kaki naga ikan (Gambar 8) yang diajarkan oleh tim PKM.

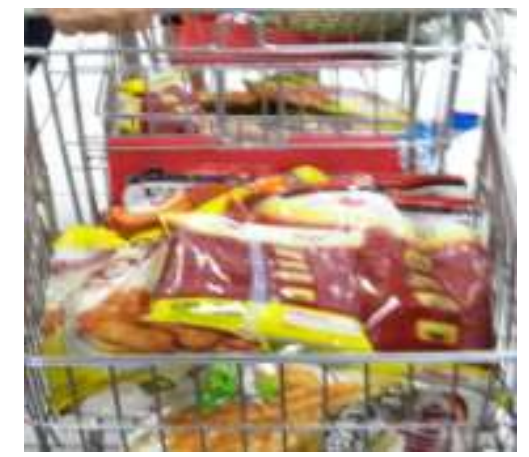

Gambar 4. Bahan-bahan untuk pembuatan nugget dan kaki naga ikan.

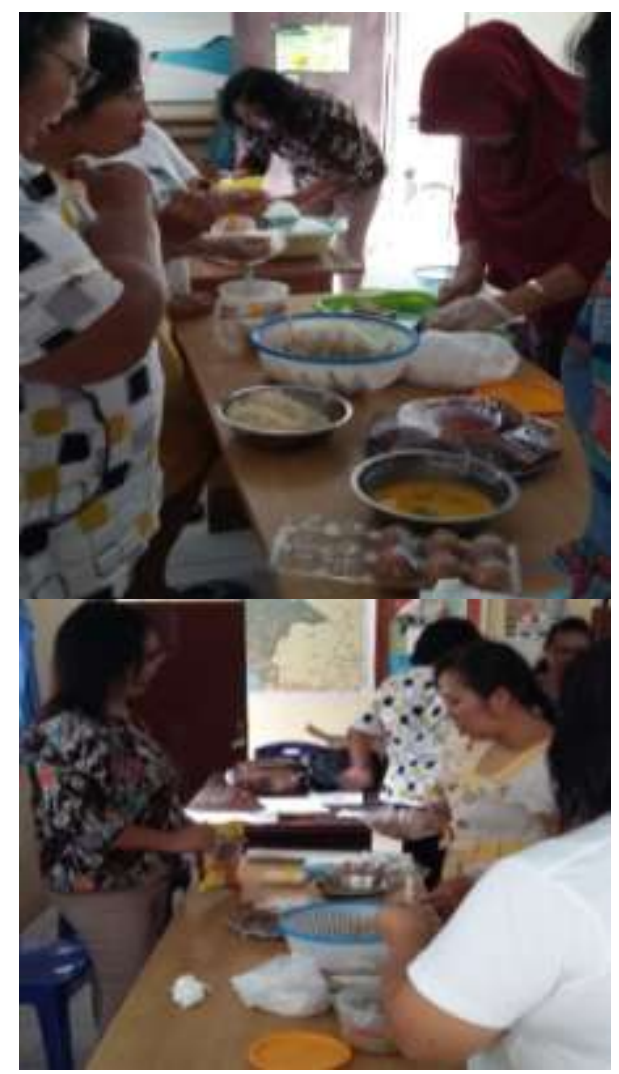

Gambar 5. Peragaan cara pembuatan nugget dan kaki naga ikan oleh Tim kepada mitra PKM. 


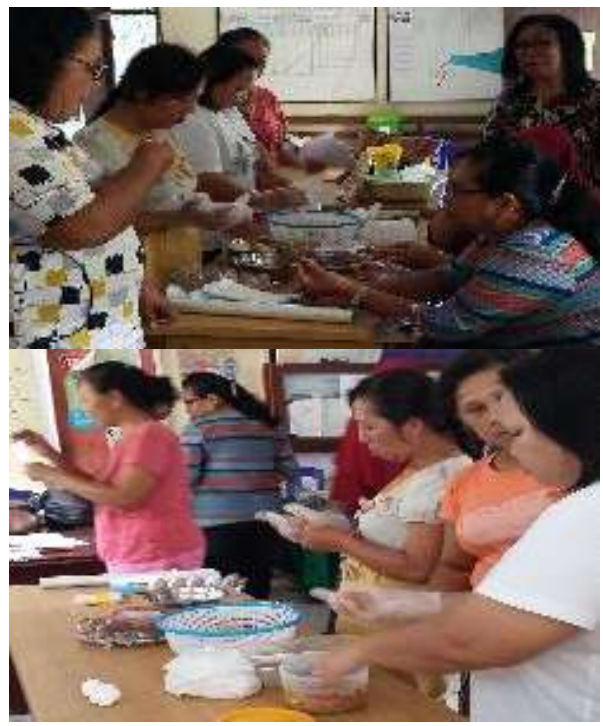

Gambar 6. Mitra PKM membuat sendiri nugget dan kaki naga ikan didampingi oleh Tim PKM.

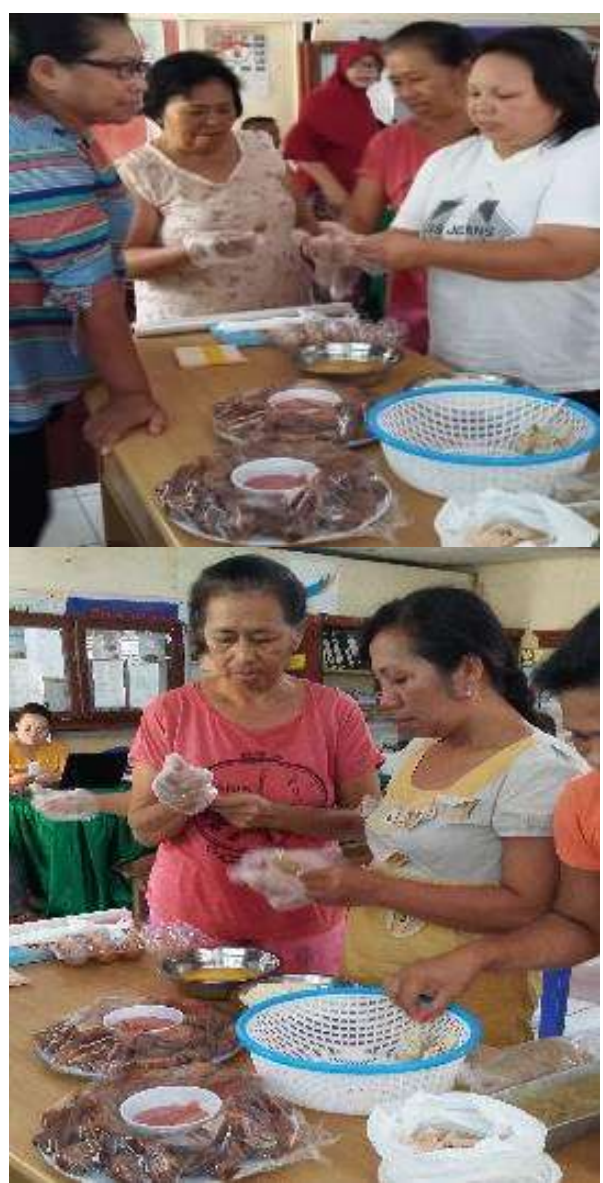

Gambar 7. Mitra PKM membuat sendiri nugget dan kaki naga ikan didampingi oleh tim PKM.

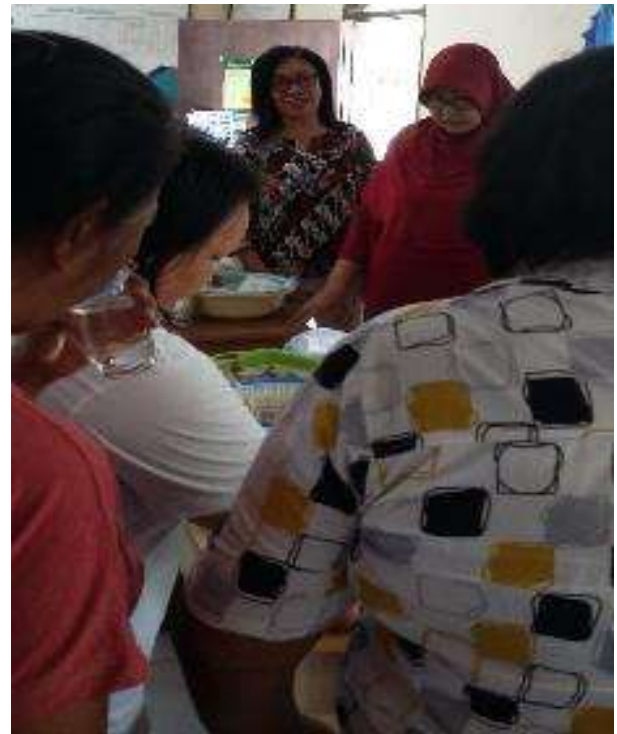

Gambar 8. Pendampingan dan evaluasi kegiatan PKM.

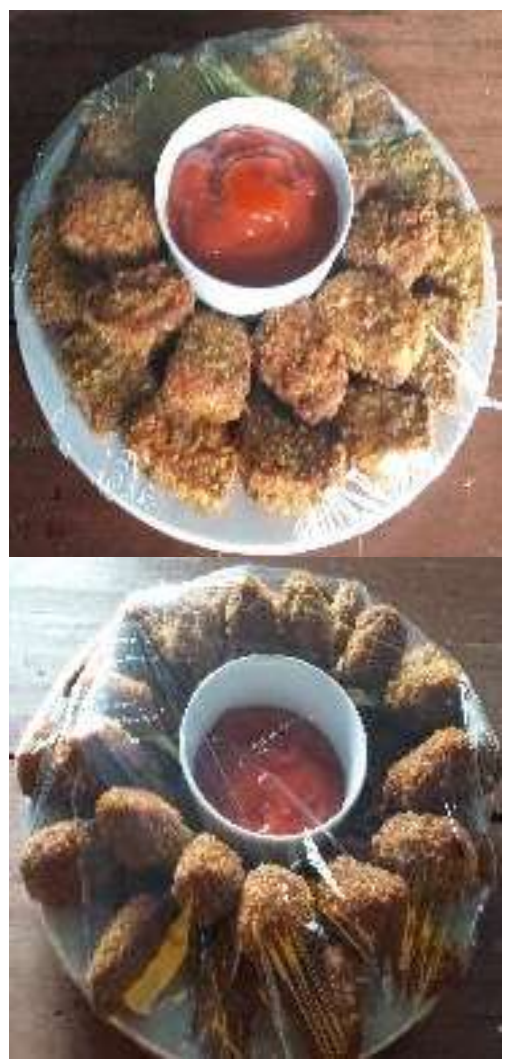

Gambar 9. Nugget dan kaki naga ikan hasil kegiatan PKM.

\section{KESIMPULAN}

1. Kelompok mitra sudah mengerti manfaat makan ikan baik bagi anak-anak maupun orang dewasa serta bagaimana menjaga agar ikan yang akan diolah tetap segar.

2. Kelompok mitra telah mengerti tentang pentingnya diversifikasi olahan ikan untuk meningkatkan kegemaran makan ikan 
(Gemarikan) terutama untuk anak-anak balita.

3. Kelompok mitra sudah bisa membuat sendiri produk diversifikasi olahan ikan yang dilakukan dalam kegiatan PKM yaitu nugget dan kaki naga ikan.

Secara keseluruhan, setelah dilakukan kegiatan PKM maka terjadi peningkatan pengetahuan pada ibu-ibu PKK (istri nelayan) di Desa Molas tentang manfaat makan ikan bagi kesehatan dan bagaimana membuat nugget dan kaki naga ikan sebagai makan sehat, bergizi dan mempunyai rasa yang lezat yang bisa dikembangkan sebagai skala usaha rumah tangga.

\section{DAFTAR PUSTAKA}

Anonimous. 2007. Peningkatan Peran Sektor Perikanan dan Kelautan Sebagai Sumber Ekonomi. Departemen Kelautan Perikanan RI.
Erjanan, S., Dotulong, V dan Montolalu, R. 2017. Mutu Karaginan dan Kekuatan Gel dari Rumput Laut Merah kappaphycus alvarezii. Jurnal Media Teknologi Hasil Perikanan Vol. 5, No. 2, Agustus 2017.

Ilyas, S. 1983. Penerapan Sanitasi dan hygiene Dalam Industri Perikanan. Lembaga Teknologi Perikanan. Jakarta.

Masita,H. I dan Sukesi. 2015. Pengaruh Penambahan Rumput Laut terhadap Kekerasan Nugget Ikan. Jurnal Sains dan Seni Its Vol. 4, No.1, (2015) 2337-3520 (2301-928X Print).

[Permentan]. Program Diversifikasi dan Ketahanan Pangan Masyarakat Badan Ketahanan Pangan Tahun Anggaran 2013. Kementerian Pertanian. Jakarta.

Poernomo, H.S. 2002. Teknologi Pengolahan Ikan. Departemen Kelautan dan Perikanan. Pusat Pendidikan dan Pelatihan Perikanan.

Saparinto C. 2011. Fishpreneurship. Variasi Olahan Produk Perikanan Skala Industri dan Rumah Tangga. 